\title{
A Clinical Evaluation of Management of Amavata with Rasonadi kwatha, w.s.r. to Rheumatoid Arthritis
}

\author{
Neelakanta Sajjanar', Debajit Bhattacharyya ${ }^{2}$, Shobha Innal $^{3}$ \\ ${ }^{1}$ Assistant Professor, Department of Post-Graduate Studies in Kayachikitsa, Sri Sri College of Ayurvedic Science and \\ Research, Bangalore, Karnataka, India. \\ ${ }^{2}$ Former Head of the Department (Late), Department of Post-Graduate Studies in Kayachikitsa, ALN Rao Memorial \\ Ayurvedic Medical College, Koppa, Chikkamagaluru, Karnataka, India. \\ ${ }^{3}$ Professor, Department of Kayachikitsa, Shri J G C H S Ayurvedic Medical College, Ghataprabha, Karnataka, India. \\ DOI: https://doi.org/10.24321/2394.6547.201807
}

Abstract
Purpose: To evaluate the role of Rasonadi kwatha, a classical medicament in the management of Amavata,
w.s.r. to Rheumatoid Arthrits, which is attributed with best Amavatahara property, considering a trend of
progressively increasing incidence of the condition.
Methods: The trial drug Rasonadi kwatha was prepared as per the classical method of Kashaya kalpana.
Total of 47 patients of Amavata fulfilling the inclusion criteria were registered, of which 30 completed
the course of intervention, in a single armed, prospective, open label, cohort study, with pre and post-
intervention analysis design. Descriptive data including Mean, Standard Deviation (SD), Standard Error (SE),
t-value and percentages were calculated for all variables in the trial group. The post treatment changes
were assessed by paired Student t-test, taking 0.05 as the level of significance.
Results: Effect of the intervention on Subjective criteria including Signs and symptoms of Amavata and
objective criteria including Disease Activity Score 28, Grip strength, Foot Pressure and Range of Movement
was statistically significant with P value 0.001 after completion of treatment. The trial drug showed $36.67 \%$
of Moderate improvement and $53.33 \%$ of mild improvement in subjects of Amavata in the present study.
Conclusion: The formulation Rasonadi kwatha is efficacious in management of the disease Amavata w.s.r.
to Rheumatoid Arthritis. The formulation is Ruksha (Dry) and Ushna (Hot potency) and thus it is a potent
Amapachaka (digesting the Ama), breaking the primary pathogenesis of the disease. It showed statistically
significant improvements in Samanya lakshanas and good results in Pradhana lakshanas of Amavata.
Keywords: Amavata, Disease Activity Score 28 , Rheumatoid Arthritis, Rasonadi kwatha

\section{Introduction}

Rheumatoid Arthritis (RA) is one of the commonest debilitating diseases by virtue of its chronicity and complications. The incidence of RA is reported to be 1 to $1.5 \%$ of general population with female to male ratio of 3:1 and is progressively increasing in incidence owing to erroneous lifestyle and food habits. ${ }^{1}$

Corresponding Author: Dr. Neelakanta Sajjanar, Department of Post-Graduate Studies in Kayachikitsa, Sri Sri College of Ayurvedic Science and Research, Bangalore, Karnataka, India.

E-mail Id: neelkant.ayu@gmail.com

Orcid Id: https://orcid.org/0000-0003-0669-1028

How to cite this article: Sajjanar N, Bhattacharyya D, Itnal S. A Clinical Evaluation of Management of Amavata with Rasonadi kwatha, w.s.r. to Rheumatoid Arthritis. J Adv Res Ayur Yoga Unani Sidd Homeo 2018; 5(2): 3-7. 
Amavata displays many features in common with a collection of signs and symptoms that are typically diagnosed as RA. ${ }^{2}$ All the diseases of systemic origin have their base in Agnimandya (poor digestive capacity), as described by Vagbhata. One among these is a serious agonizing painful condition called Amavata.

The present study was taken up to evaluate the role of a classical combination Rasonadi kwatha, in the management of Amavata w.s.r. to Rheumatoid Arthritis, which is attributed with best Amavatahara property, taken from Amavata chikitsadhikara of Bhaishajya ratnavali. ${ }^{3}$

The objective of the study was to assess the role of the research drug 'Rasonadi kwatha' in management of Amavata w.s.r. to Rheumatoid Arthritis.

\section{Selection of Intervention}

Trial drug in the present study was selected considering the easy availability of ingredients (Garlic, Dryginger and Vitex negundo), cost effectiveness and convenience and compliance. The combination is Katu (Pungent), Tikta (Bitter) in taste and except Amla (Sour) all others tastes are present in small amounts, it is mainly Ruksha (Dry) and Teekshna (penetrating) in property, Ushna (Hot) in potency, predominantly Katu (Pungent) vipaka, Kapha-vatahara and Deepana (digestive). The formulation Rasonadi kwatha is Ruksha (Dry) and Ushna (Hot potency) and is Amapachaka in nature. It acts a gainst the properties of $A m a$, and it reduces the generalized Amalakshanas which are nothing but Samanyalakshanas of Amavata. The formulation is potent enough to act at the level Asthi Sandhi (bone joints) which is a part of Madhyama rogamarga (deepseated internal diseases).

\section{Materials \& Methods}

A single armed, prospective, open label, cohort study, with pre and post-intervention analysis design was conducted at ALN Rao Memorial Ayurvedic Medical College Hospital, Koppa, Chikkamagaluru district, Karnataka, India during January and October 2011. The patients attending Out Patient Department (OPD) and In-Patient Department (IPD) were thoroughly assessed for the classical lakshanas of Amavata and signs and symptoms of Rheumatoid Arthritis. The detailed history and examination findings were noted on 0 day (before trial), $15^{\text {th }}$ day (during trial), $30^{\text {th }}$ day (after trial) and $75^{\text {th }}$ day ( 45 days of followup) and the changes in observations were documented in a specially designed Case proforma. Institutional Ethical Clearance Number assigned to the study is 191/CPCSEA.

\section{Inclusion Criteria}

- Age group $>20$ years and $<60$ years

- Patients diagnosed as having Amavata on the basis of classical symptoms and Rheumatoid Arthritis on basis of ACR (American College of Rheumatology) criteria for diagnosing Rheumatoid Arthritis ${ }^{4}$

- $\quad<1$ year of chronicity

- Both fresh and treated (discontinuing the existing medicines)

\section{Exclusion Criteria}

- Other complicated arthritic diseases

- Complications of RA including deformities, contractures, nodules, etc

- Other serious systemic, complicated diseases

- Pregnant and lactating women

\section{Diagnostic criteria}

\section{Primary criteria}

Signs of Amavata i.e. Pradhana Lakshanas, Shoola (Tenderness), Shopha (Swelling), Stabdhata (Stiffness) (with grading 0-absent, 1-mild, 2-moderate, 3-severe) of Joints, vis-à-vis Rheumatoid Arthritis.

\section{Secondary criteria}

Samanya lakshanas of Amavata, i.e. Angamarda (Generalized body ache), Aruchi (Tastelessness), Aalasya (Lack of enthusisasm), Jwara (Feverishness), Apaka (Lack of digestion) (with grading 0-absent, 1-mild, 2-moderate, 3-severe).

\section{Assessment criteria}

On 0 day (before trial), $15^{\text {th }}$ day (during trial), $30^{\text {th }}$ day (after trial) and $75^{\text {th }}$ day ( 45 days of follow up), analysis of role of the trial drug in breaking the pathology of Amavata was assessed based on:

\section{Subjective parameters}

\section{- Pradhana and Samanya lakshanas of Amavata}

\section{Objective parameters}

- $\quad$ DAS28 (Disease Activity Score 28$)^{5}$ and the response of the disease to the clinical intervention, using EULAR response criteria

- $\quad$ Grip strength with appropriate grading

- Foot pressure with appropriate grading

- Goniometric assessment of range of movement

- Functional ability (RA Quality of Life ${ }^{6}$ )

\section{Investigations}

- $\quad$ Erythrocyte Sedimentation Rate (ESR)

- Rheumatoid factor (RF) test

- Radiological: X-ray of afflicted joints (if needed) 


\section{Intervention}

\begin{tabular}{|c|c|}
\hline Sample size & 30 irrespective of gender \\
\hline Drug & Rasonadi kwatha \\
\hline Dose & $\begin{array}{c}25 \mathrm{ml} \text { twice daily (6 am and } 6 \mathrm{pm}), \\
\text { Ananna kala }\end{array}$ \\
\hline Anupana & Hot water q.s. (if required) \\
\hline $\begin{array}{l}\text { Duration of } \\
\text { treatment }\end{array}$ & 30 days \\
\hline Follow up & $\begin{array}{l}45 \text { days after completion of treatment } \\
\text { schedule (without any medication and } \\
\text { with strict diet advised) }\end{array}$ \\
\hline
\end{tabular}

The trial drug was prepared according to the classical method of Kwatha kalpana ${ }^{7}$, in the Pharmacy attached to the institution. Preparation was in two batches of 40 lts each, bottled in $450 \mathrm{ml}$ containers. $2 \mathrm{~g} / \mathrm{l}$ of Sodium benzoate as a preservative was added.

\section{Statistical Analysis}

Descriptive data including Mean, Standard Deviation (SD), Standard Error (SE), t-value and percentages were calculated for all variables in the trial group. The post treatment changes were assessed by paired Student t-test, taking 0.05 as the level of significance.

\section{Results}

In the present study totally 47 patients of Amavata fulfilling the inclusion criteria were registered under the trial group. Out of 47 patients, 10 patients did not come back for any follow up and 7 patients discontinued after 1st follow up visit, against medical advice. So, a total of 30 patients completed the study. Major part of the sample (50\%) were in age group of 41 and 50yrs and Females (90\%). 40\% of the sample had family history of Amavata. $80 \%$ were non-vegetarians. $46.7 \%$ had Krura koshta (Constipated) and $66.67 \%$ had reduced aharashakti (Digestive capacity) and vyayama shakti (Physical strength). 83.33\% were from Anupa desha (Marshy land). Sandhi Shoola (Tenderness) was common in all the subjects (100\%), Sandhi Stabdhata
(Stiffness) 93.34\% and Sandhi Shopha (Swelling) in 90\%.

Among Samanya lakshanas Angamarda (Generalized body ache) (100\%), Apaka (Lack of digestion) in (80\%) and Aalasya (Lack of enthusiasm) (96.7\%) were predominantly present. Viruddha ahara (improper food habits) $(46.7 \%)$, Early morning $(86.7 \%)$ and Cold season (86.7\%) were predominant Aggravating factors. Pathya ahara (Wholesome food) (53.3\%), Day time (60\%), Hot season (60\%), Movements (53.3\%) and use of Ushna (Hot potency) Ruksha (Dry) food and regimens (90\%) were predominant Relieving factors. Among the subjects, $63.3 \%$ were positive for Rheumatoid factor.

Effect of Rasonadi kwatha on Pradhana lakshana was statistically significant with $P$ value 0.001 after completion of treatment.

Effect on Samanya lakshanas was statistically significant with $P$ value 0.001 after completion of treatment, except for Trushna which was statistically insignificant with $P$ value $>0.1$.The intervention showed moderate improvement of $63.3 \%$ in Disease Activity Score 28 (DAS 28) after completion.

Effect on Grip strength, Foot Pressure and Range of Movement was statistically significant with $P$ value 0.001 after completion of treatment. Overall, the trial drug Rasonadi kwatha showed $36.67 \%$ of Moderate improvement and $53.33 \%$ of mild improvement in subjects of Amavata in the present study. Details are depicted in Table No. 1-4 and Graph No.1.

\section{Assessment of Disease Specific Quality of Life (QoL)}

Disease specific QoL questionnaire measured all the subjective parameters of the disease and the patients' feeling of improvements in their day to day activities comprehensively. This could be used as a valuable tool in assessing the subjective improvements in the patients. $54 \%$ of patients showed a significant improvement in the domains of dressing and grooming, rising, eating, walking, hygiene, reach, grip and activities after the completion of treatment duration and $37 \%$ of patients showed improvement after follow up of 45 days.

Table 1.Effect of trial drug on Pradhana lakshanas AT and AF

\begin{tabular}{|c|c|c|c|c|}
\hline \multirow{2}{*}{ Pradhana Lakshana } & \multicolumn{2}{|c|}{ Result after treatment (30 days) } & \multicolumn{2}{c|}{ Result After follow up } \\
\cline { 2 - 5 } & Percentage & P value & Percentage & P value \\
\hline Shoola (Tenderness) & $52 \%$ & $<0.001$ & $41.33 \%$ & $<0.001$ \\
\hline Shopha (Swelling) & $58.49 \%$ & $<0.001$ & $39.62 \%$ & $<0.001$ \\
\hline Stabdhata (Stiffness) & $50 \%$ & $<0.001$ & $44 \%$ & $<0.001$ \\
\hline
\end{tabular}


Table 2.Effect of trial drug on Samanya lakshanas AT and AF

\begin{tabular}{|c|c|c|c|c|}
\hline \multirow{2}{*}{ Pradhana Lakshana } & \multicolumn{2}{|c|}{ Result after treatment (30 days) } & \multicolumn{2}{c|}{ Result after After follow up } \\
\cline { 2 - 4 } & Percentage & p value & Percentage & $<$ value \\
\hline $\begin{array}{c}\text { Angamarda } \\
\text { (Generalized body ache) }\end{array}$ & $72.58 \%$ & $<0.001$ & $66.12 \%$ & $<0.001$ \\
\hline Aruchi (Lack of digestion) & $83.33 \%$ & $<0.001$ & $75 \%$ & $<0.001$ \\
\hline Trushna (Increased thirst) & $-18.18 \%$ & $>0.1$ & $45.45 \%$ & $<0.001$ \\
\hline Aalasya (Lack of enthusiasm) & $66.07 \%$ & $<0.001$ & $62.50 \%$ & $<0.001$ \\
\hline Apaka (Indigestion) & $79.59 \%$ & $<0.001$ & $69.38 \%$ & $<$ \\
\hline
\end{tabular}

Table 3.Effect of trial drug on objective parameters AT and AF

\begin{tabular}{|c|c|c|c|c|}
\hline \multirow{2}{*}{ Objective parameters } & \multicolumn{2}{|c|}{ AT } & \multicolumn{2}{c|}{ AF } \\
\cline { 2 - 5 } & Percentage & p value & Percentage & p value \\
\hline DAS28 & $63.33 \%$ & - & $33.33 \%$ & - \\
\hline Grip strength & $40.32 \%$ & $<0.001$ & $33.87 \%$ & $<0.001$ \\
\hline Foot pressure & $43.24 \%$ & $<0.001$ & $29.72 \%$ & $<0.001$ \\
\hline Functional assessment & $65.71 \%$. & $<0.001$ & $51.42 \%$ & $<0.001$ \\
\hline
\end{tabular}

Table 4.Overall result of the trial drug

\begin{tabular}{|c|c|c|c|c|c|c|c|c|}
\hline \multirow{3}{*}{ Trial group } & \multicolumn{7}{|c|}{ Result of the treatment } \\
\cline { 2 - 9 } & \multicolumn{1}{|c|}{ Remarkable improvement } & Moderate improvement & Mild improvement & \multicolumn{2}{|c|}{ No improvement } \\
\cline { 2 - 9 } & No of patients & $\%$ & No & $\%$ & No & $\%$ & No & $\%$ \\
\hline After treatment & 0 & 0 & 11 & $36.67 \%$ & 16 & $53.33 \%$ & 3 & $10 \%$ \\
\hline After follow up & 0 & 0 & 06 & $20 \%$ & 19 & $63.33 \%$ & 5 & $16.67 \%$ \\
\hline
\end{tabular}

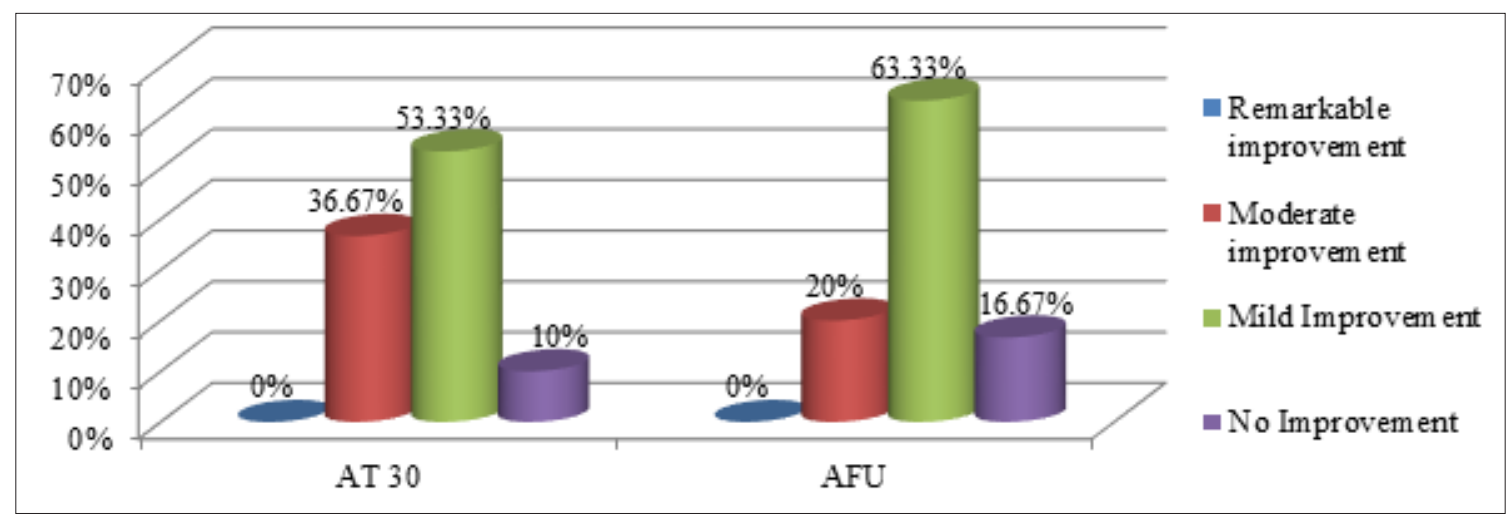

Figure 1.Overall effect of the trial drug Rasonadi kwatha in management of Amavata

\section{Discussion}

Recent trends of management of RA highlights using Disease Modifying Anti Rheumatic Drugs (DMARD) of varied classes for early arrest of disease progression in terms of Subjective and functional parameters. ${ }^{8}$ Other treatments include Non steroidal anti-inflammatory drugs (NSAID) and Gluco corticoids along with other non-pharmacological approaches of management ${ }^{9}$. All the pharmacological interventions, including Methotrexate, a common DMARD, are proved to have multiple Adverse Effects, including Hepato-Renal toxicity. ${ }^{10}$
The present study based on Ayurvedic principles of treating the condition as per the clinical and pathological stage, (stage of $A m a$ ) have shown significant improvements in the symptoms (of Ama and Amavata) and considerable improvements in ESR which is used in the DAS28 calculation of the samples. Also there was a significant improvement in functional aspects (Foot pressure, Grip strength, Range of Movement and RA quality of life questionnaire).

During the study it was observed that:

- Amavata mostly affects people of age group 41-60 years. 
- Positive family history may be a risk factor for causality of Amavata.

- The trial drug is most effective in Avastha of the disease with Kapha and Vata predominance and should be avoided in case of involvement of Pitta in the samprapti.

- $\quad$ There were no significant changes in RA factors observed.

- The formulation is cost effective in the management of Amavata.

- Nidana parivarjana (avoiding the causative factors) had a major role in controlling the progression of this disease.

- The formulation had a good effect in improving the quality of life in the patients and Disease specific Quality of Life Questionnaire could be used as a valuable and handy tool in assessing the subjective outcomes in the patients.

- The phytochemical analysis shows that the ingredients of the formulation have active ingredients which are anti-inflammatory, anti-arthritic, anti-rheumatic and also immune-modulator and immune stimulator in their action

\section{Conclusion}

The formulation Rasonadi kwatha is Ruksha (Dry) and Ushna (Hot potency) and thus it is Amapachaka (breaking the pathological stage of Ama) in nature. It showed very significant improvements in Samanya lakshanas (Symptoms of Rheumatoid Arthritis) and good results in Pradhana lakshanas (Signs of Rheumatoid Arthritis) statistically. Objective criteria (DAS 28, Range of movement, Grip strength and Foot pressure) also showed significant improvements.

After completion of intervention, the trial drug Rasonadi kwatha supported Research Hypothesis that, the formulation is efficacious in management of the disease Amavata w.s.r. to Rheumatoid Arthritis. Also, the combination had good effect even in the period of follow up with strictly advised Pathyapathya (diet regimen) during the whole study.

\section{Conflict of Interest: None}

\section{References}

1. Colledge NR, Walkar BR, Ralstan HS. Davidson's principle sand practice of medicine. $20^{\text {th }} \mathrm{ed}$., Churchill Livingstone, Toronto. 2006: 1101-1106.

2. Edwards CRW, Haslett C, Chilvers E et al. Davidson's principles and practice of medicine. $17^{\text {th }}$ ed., Churchill Livingstone, Edinburgh. 1995: 838.

3. Sen G. Bhaisajya Ratnavali. $18^{\text {th }}$ ed. Chaukhamba Prakashan, Varanasi. 2007: 615.

4. Arnett FC, Edworthy SM, Bloch DA et al. The American Association 1987 revised criteria for the classification of rheumatoid arthritis. Arthritis Rheumatism 1988; 31: 315-24.

5. Prevoo MLL, Van 'T Hoff MA. Modified disease activity scores that include twenty-eight-joint counts. Arthritis Rheumatism 1995; 38: 44-8.

6. Greenwood MC, Hakimn AJ, Doyle DV. A simple extension to the Rheumatoid Arthritis Quality of Life Questionnaire (RAQol) to explore individual patient concerns and monitor group outcome in clinical practice. Rheumatology 2006; 45(1): 61-5.

7. Sharngdhara. Sharngdhara samhita.Varanasi: Chaukhamba surabharati prakashan; 2006: 144.

8. Therapy of rheumatoid arthritis: new developments and trends. St Clair EW, Curr Rheumatol Rep 1999 Dec; 1(2): 149-56

9. Smolen JS, Landewe R, Bijlsma J et al. EULAR recommendations for the management of rheumatoid arthritis with synthetic and biological disease-modifying antirheumatic drugs: 2016 update. Ann Rheum Dis 2017; 76(6): 960-977.

10. Rheumaklinik, Ratingen, Germany. Rolf Rau, MD; Gertraud Herborn, MD. Benefit and risk of methotrexate treatment in rheumatoid arthritis, Clin Exp Rheumatol 2004; 22 (Suppl. 35): S83-S94.

Date of Submission: 2018-08-19 Date of Acceptance: 2018-09-19 